\title{
The Effect of Loving Pregnancy Massage on Sleep Quality of Trimester III Pregnant Mother
}

\author{
Sri Wahyuni Rahayu1); Sinar Pertiwi'2) Etin Rohmatin ${ }^{3)}$ \\ sri.wahyunirahayu95@gmail.com
}

\begin{abstract}
Background: Third trimester of pregnancy was the peak of discomfort that was often experienced by pregnant women due to physical changes and psychological changes, which cause the mother's sleep was not quality. Treatment of sleep disorders can be overcome by pharmacological and non-pharmacological ways. Loving pregnancy massage provides a relaxing effect that can help solve discomfort problems, especially those related to sleep disorders..

Methods: This study used a pre-experimental method with one group pretest-posttest design. The population of this study were pregnant women in their third trimester in Purbaratu Health Center, Tasikmalaya City. A sample of 31 people was taken by purposive sampling. The dependent variable was the sleep quality of the third trimester of pregnant women and the independent variable is loving pregnancy massage. The research instrument used The Pittsburgh Sleep Quality Index (PSQI) questionnaire with Wilcoxon test data analysis.

Results: The results showed that the sleep quality of pregnant women before doing massage was in the moderate sleep disorder category (64.5\%) and after the massage there was a decrease in the quality of sleep into a good category (54.8\%). The Wilcoxon test results obtained a significance value of 0.000 .

Conclusion: there was a relationship between loving pregnancy massage and the sleep quality of third trimester pregnant women.
\end{abstract}

\section{Keyword : Loving Pregnancy Massage; Sleep Quality; Pregnant Mother}

\section{1,2,3) Midwifery Department, Poltekkes Kemenkes Tasikmalaya Indonesia \\ Jl. Babakan Siliwangi No.35, Kahuripan, Kec. Tawang, Tasikmalaya, Jawa Barat}

Background. During pregnancy, the mother experiences various complaints that cause discomfort due to physical changes as well as psychological changes. The physical changes that were often experienced during pregnancy include back pain, leg cramps, shortness of breath, frequent urination and psychological responses experienced by pregnant women in the form of depression, stress, anxiety and sleep disorders such as insomnia or difficulty starting to sleep. Menurut National Sleep Foundation (2017) According to the National Sleep Foundation (2017) 78\% of women in America complain of sleep disturbances during pregnancy compared to when they are not pregnant.

About $80 \%$ of mothers experience sleep disturbances during pregnancy due to physiological changes so that pregnant women find it difficult to start sleeping and find it difficult to get a comfortable position while sleeping, hot or hot, low back pain and muscle tension (Wahyuni, 2012). In the third trimester, stress and anxiety in pregnant women will increase, this happens because the condition of the pregnancy was getting bigger and the psychological condition of the third trimester was more complex. This condition often causes problems such as uncomfortable sleeping position and fatigue, and the closer the delivery time will make the mother's stress level higher. Feelings of anxiety arise because the mother is worried about the labor process, labor pains and the condition of the baby who will be born later. Research conducted by Kathryn (2014) at the maternity home. In a prospective observational study of 131 third trimester pregnant women stated that pregnant women who slept less than 6 hours at night had a prolonged labor risk with 4.5 times more likely to have cesarean delivery and underweight babies. Pregnant women with disrupted sleep duration have prolonged straining and are at risk for cesarean delivery.

Sleep disorders experienced by pregnant women can be overcome in various ways, including by using pharmacological and nonpharmacological techniques. The pharmacological method is given to sufferers who experience sleep disorders, namely by giving sedative-hypnotic drugs that give a quick effect but if given in the long term it can cause 
dangerous effects on the health of pregnant women because it can pose a risk of impaired fetal growth and development. One of the nonpharmacological methods recommended for pregnant women in overcoming sleep disorders during pregnancy is pregnancy massage, acupuncture, relaxation, chiropactic therapy (Field et al, 2010).

The results of a preliminary study conducted by researchers by interviewing 10 trimester III pregnant women on November 14162018 at Purbaratu Puskesmas, Tasikmalaya City 8 Pregnant women experience sleep disturbances due to restlessness and sleeping late at night, often wake up at night and have trouble starting to sleep (insomnia). The average length of sleep for pregnant women is 7-8 hours and wakes up 3-4 times in one night which causes sleeplessness until morning. And 2 people said it was difficult to start sleeping because of fetal movements and the mother felt anxious before delivery.

The aim of this research was to know the effect of loving pregnancy massage on sleep quality of third trimester pregnant mother

Methods. This research method used a pre-experimental method with the design of One Group Pretest-Posttest Design. The research was conducted in the Purbaratu Puskesmas, Tasikmalaya City in JanuaryFebruary 2019. The population in this study were pregnant women in the third trimester in the Purbaratu Health Center, Tasikmalaya City, with a sample who were taken by purposive sampling. The measurement of sleep quality used the Pittsburgh Sleep Quality Index (PSQI) questionnaire and as long as the mother met the inclusion and exclusion criteria, the mother was massaged. The relationship between variables was tested by the Wilcoxon test

\section{Result and Discussion.}

Table 1. Frequency distribution of sleep quality for third trimester pregnant women before loving pregnancy massage

\begin{tabular}{|l|c|c|}
\hline \multicolumn{1}{|c|}{ Kategori } & F & $\%$ \\
\hline Good sleep disturbance & 0 & 0 \\
\hline Mild sleep disturbance & 10 & 32,3 \\
\hline Moderate sleep disturbance & 20 & 64,5 \\
\hline Severe sleep disturbance & 1 & 3,2 \\
\hline \multicolumn{1}{|c|}{ Total } & 31 & 100 \\
\hline
\end{tabular}

Table 2. Frequency Distribution of Sleep Quality for Third Trimester of Pregnant Women After Loving Pregnancy Massage

\begin{tabular}{|l|c|c|}
\hline \multicolumn{1}{|c|}{ Kategori } & F & $\%$ \\
\hline Good sleep disturbance & 17 & 54,8 \\
\hline Mild sleep disturbance & 7 & 22,6 \\
\hline Moderate sleep disturbance & 7 & 22,6 \\
\hline Severe sleep disturbance & 0 & 0 \\
\hline Total & 31 & 100 \\
\hline
\end{tabular}

The results of wilcoxon test show correlation between the two variables is $-4,463$ with a significance of 0,000 . From these results it can be seen that the significance value obtained is 0.000 smaller than the $\alpha$ value (0.05), so Ho is rejected, which means that there is an effect of loving pregnancy massage on the sleep quality of pregnant women in the third trimester.

The results of this study are in line with study of Resmaniasih (2017), the quality of sleep in third trimester pregnant women between groups of pregnant women who were given massage and those who were not given massage, obtained a significance value of 0.049 which is smaller than the $\alpha$ value (0.05), which means that there is a significant difference between the differences. the average sleep quality of third trimester pregnant women who were given massage and those who were not given massage. Pregnant massage can be done as a way to relieve discomfort and make pregnant women relax and sleep well. Action massage for pregnant women is given 4 times in 2 consecutive weeks Another study conducted by Atika (2013) that giving massage for a long time can provide a deeper relaxing effect, maximize the process of stretching muscles and increase tissue elasticity. Loving massage in pregnancy is effective toward sleep patterns in pregnant women Primigravida (Prananingrum \& Hidayah, 2018).

Pregnant women experience changes physically, some of this physical can result stress and discomfort. Massage for pregnancy is one way suitable for reducing stress and improve the well-being of mother and baby. Benefits and benefits of pregnant massage including: increasing relaxation, improves sleep patterns, helps reduce edema, support health uterus, relieves tension, stress reduce pain and anxiety, improve changes in posture 
in pregnancy, create a harmonious relationship between mothers and babies, relieves back, shoulder and neck pain in pregnant women and conditions muscles in general in pregnancy, help stabilizes hormonal changes and stress blood, encourages deeper breathing, increase internal respiration, reduce nausea, stimulates peristaltic activity, relieves muscle tension, restores posture balance, normalize wide range of motion, accelerate circulation veins and lymph, carrying nutrients to network and eliminate products toxins from the body, reduce swelling, relieves varicose veins, normalizes pressure blood, elevates the mood of the day or mood, encourages loving maternal care, prepare physically, emotionally and mentally mother to face the puerperium. Massage can help calm and relaxes frequent pregnant women experiencing anxiety, so that the mother is pregnant can experience better quality sleep. Pregnant women who are relaxed will feel more happy, healthy and give birth smoothly (Sutarmi et al. 2014; Prananingrum \& Hidayah, 2018)

Conclusion and Suggestions. Based on the results of research and discussion, it is concluded that there is a relationship between loving pregnancy massage and the sleep quality of third trimester pregnant women. With an overview of the quality of sleep of third trimester pregnant women before loving pregnancy massage, most of them were in the moderate sleep disorder category, which was $64.5 \%$ and after loving pregnancy massage, most of them were in the good category, namely $54.8 \%$.

Acknowledgements. Thanks to the researchers say to all those who have helped in completing this research.

\section{References}

Atika, AF. 2013. Pengaruh Back Massage Terhadap Kualitas Tidur pada Ibu Hamil Trimester Tiga.

Dahlan, MS. 2016. Pintu Gerbang Memahami Statistik, Metodologi dan Epidemiologi (Edisi 2). Jakarta : Epdemiologi Indonesia

Field et al. 2010. Prenatal Depression Effects and Intervention: a review. Infant Behavior and Development, 33(4), 409418.
Harahap, S. D., Utami \& Nurul. 2018. Efektivitas Yoga Terhadap Kualitas Tidur Ibu Hamil. Riau : Universitas Riau

IHCA (Indonesian Holistic Care Association). 2014. Touch Trainning : Develoving Mom, Baby Massage and Spa.

Janiwarty, B dan Pieter, Z. 2013. Pendidikan Psikologi untuk Bidan: Suatu Teori dan Terapannya Edisi 1. Yogyakarta: Rapha Publishing.

Kemenkes RI. 2014. Pegangan Fasilitator Kelas Ibu Hamil. Jakarta: Kementerian Republik Indonesia.

Prananingrum, R. Hidayah, N. 2018. Efektifitas Loving Massage In Pregnancy Terhadap Pola Tidur Pada Ibu Hamil Primigravida di Wilayah UPTD Puskesmas Pajang Kota Surakarta

Prawirohardjo, S. 2013. Ilmu Kebidanan. Jakarta: PT Bina Pustaka.

Resmaniasih, K. 2017. Pengaruh Pijat Hamil Terhadap Perubahan Kualitas Tidur Ibu Hamil Trimester Tiga,

Romauli, S. 2011. Buku Ajar Asuhan Kebidanan I Konsep Dasar Asuhan Kbehamilam. Yogyakarta: Nuha Medika.

Ronald, HS. 2011. Pedoman dan Perawatan Kehamilan Yang Sehat dan Menyenangkan. Bandung: CV Nuansa Aulia.

Sarifansyah. 2018. Hubungan Kualitas Tidur dengan Tekanan Darah pada Ibu Hamil Trimester III di Puskesmas Dinoyo Malang.

Sulisdiana. 2017. Pengaruh Pijat Bumil terhadap Kualitas Tidur pada Ibu hamil Trimester III di BPM Bidan A Desa Karang Nongko Kabupaten Mojokerto,

Sutarmi dkk. 2014. Mom massage, baby and SPA. Semarang IHCA 
Urtnowska, K. Bulatowicz, I. Ludwikowski G. Wahyuni. 2012. Manfaat Senam Hamil untuk 2017. Massage during pregnancyindication, contraindications, general principles for performing the treatment Meningkatkan Durasi Tidur Ibu Hamil. Surakarta : Universitas Muhammadiyah Surakarta.

Venkata C\& Venkatshieah S.B. 2009. Sleep

Widyawati, M.N. Suprihatin, K. Sutarmi. (2018). Disordered Breathing During Pregnancy Loving Pregnancy Massage. Semarang: IHCA 